\title{
Effect of Brewery Effluent Irrigation and Sludge Application in Combination with Organic Amendments on Growth and Yield of Sesame (Sesamum indicum L.)
}

\author{
K. Senthilraja* \\ Department of Environmental Sciences, Tamil Nadu Agricultural University, \\ Coimbatore, Tamil Nadu 641 003, India \\ *Corresponding author
}

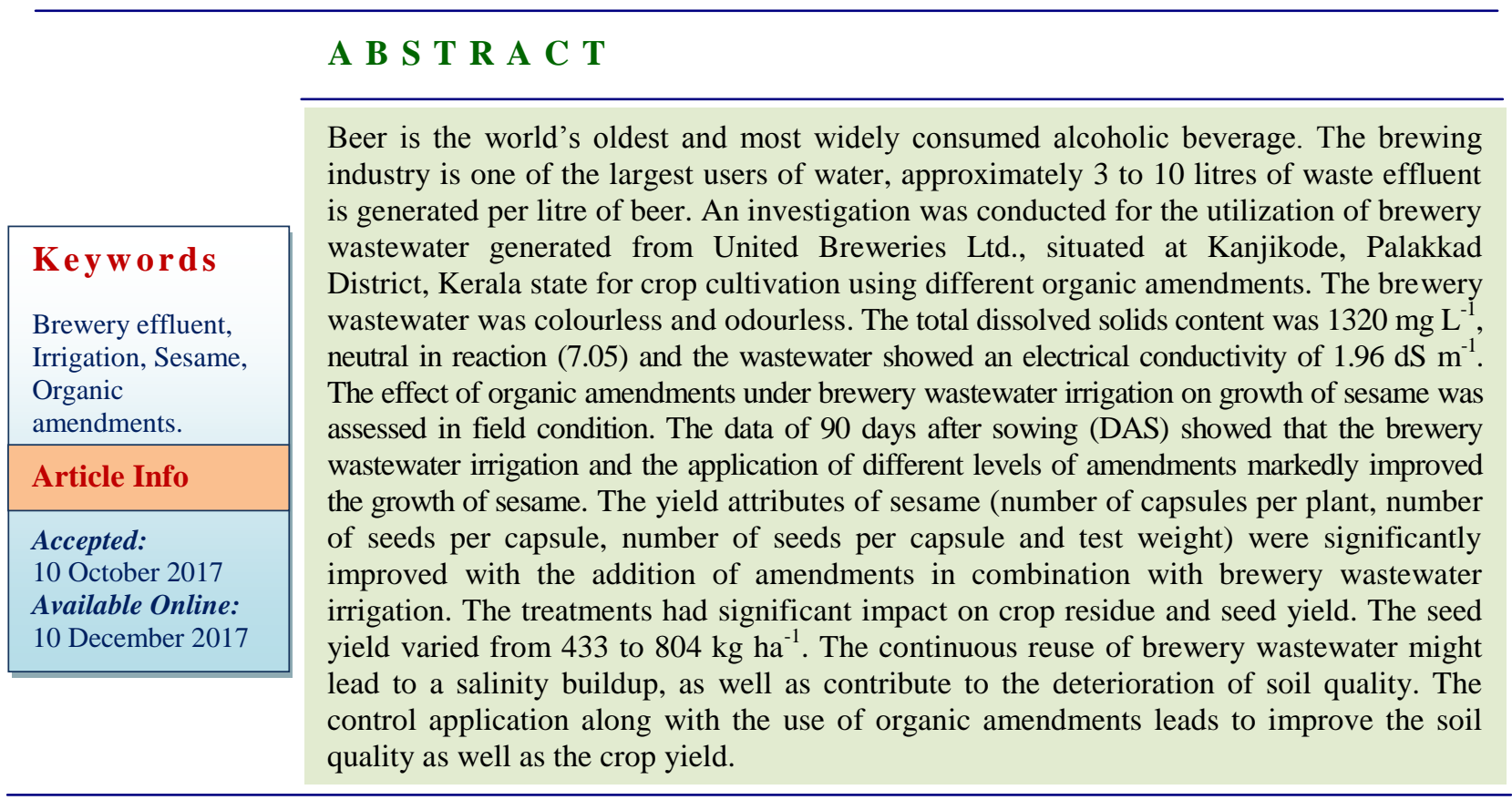

\section{Introduction}

Globally there is a great political and social pressure to reduce the pollution arising from industrial activities. Almost all developed and underdeveloped countries are trying to adapt to this reality by modifying their processes, so that their residues can be recycled. The brewing industry is one such industry that generates relatively large amounts of byproducts and wastes; spent grain, spent hops and yeast. However, as most of these are agricultural products, they can be readily recycled and reused. Thus compared to other industries, the brewing industry tends to be more environmental friendly (Ishiwaki et al., 2000). A company, which makes beer, is called either a brewery or a brewing company. Beer is the world's oldest and most widely consumed alcoholic beverage and it is produced by the brewing and fermentation of starches, mainly derived from cereal grains - 
the most common being malted barley, however wheat, maize / corn and rice are also widely used. The brewing industry is one of the largest users of water. Even though substantial technological improvements have been made in the past, it has been documented that approximately 3 to 10 litres of waste effluent is generated per litre of beer (Genner, 1988 and Manjunatha et al., 2017). In India, there are 64 brewing industries of which 6 are collaboration and the United Breweries Limited (UBL) owns 17. The United Breweries Limited, Palakkad unit discharges wastewater at the rate of 4-5 litres for every litre of beer. Biological treatment is widely applied and two treatment options are available. Generally, aerobic treatment has been applied but recently anaerobic systems have become attractive options. Since it is an oxidative biological reaction, large amounts of biomass are produced, which settle as sludge and requires further disposal. The common disposal route for brewery wastewater sludge has been through landfill. Due to increasing environmental concerns and regulations, attempts were made to utilize the brewery wastes in an eco-friendly manner.

Reuse of wastewater requires careful management to prevent the potential problems such as secondary salinisation. Qadir et al., (2003) indicated the reuse through a plantbased system, which reduced the amount of wastewater requiring further management or disposal. In the agricultural economy of India, oil seeds occupy the second position in terms of hectarage, production and value. Sesame (Sesamum indicum L.) is an important ancient oil-yielding crop. Its primary centre of origin is Africa, while India is the secondary centre. Its oil content generally varies from 46 to 52 per cent.

An investigation was conducted for the utilization of brewery wastewater generated from UBL, situated at Kanjikode, Palakkad
District, Kerala state for crop cultivation. The crop selected for management of brewery wastewater was fast growth, high salinity tolerance potential for producing commercial products such as food grains and edible oil along with the remediation capability without affecting the food grade. The present study was aimed at examining the short-term effect of brewery wastewater and sludge application on sesame crop growth and yield and evaluating whether the combinations with farm yard manure and vermicompost, and also study the yield and yield parameters of sesame crop.

\section{Materials and Methods}

Collection and preservation of brewery wastewater, sludge, farm yard manure, vermicompost, soil and plant sample

The sample of brewery wastewater were collected from United Breweries Ltd., Kanjikode west, Palakkad and analyzed for their physico-chemical and biological properties. Samples for microbiological examinations were collected in clean sterilized bottles. The sampling bottles were closed with glass stopper having an overlapping rim. An intervening strip of paper to prevent breakage of the bottle during sterilization relaxed the stopper. The stopper and neck of the bottles were protected by covering with aluminium foil and sterilized in an autoclave at $20 \mathrm{psi}$ for $15 \mathrm{~min}$. The bottles were opened only at the time of sampling. The samples for the analysis of dissolved oxygen were added with one $\mathrm{ml}$ of manganese sulphate solution and one $\mathrm{ml}$ of alkaline potassium iodide solution. Samples for the determination of biochemical oxygen demand were preserved by adding five $\mathrm{ml}$ of washed chloroform (Chloroform and distilled water were taken in a separating funnel, shaken well and the water layer was discarded) per litre of the sample (APHA, 1980). The water samples 
were stored at $4^{\circ} \mathrm{C}$ in cold room for further analysis.

Sludge, farm yard manure and vermicompost samples were collected during application and were dried under shade, powdered with wooden mallet and sieved through $2 \mathrm{~mm}$ sieve and used for further analysis. Initial surface $(0-15 \mathrm{~cm})$ soil sample was collected prior to the layout of field experiment to assess the initial status of the experimental soil.

The plant samples collected from the field at the time of harvest were dried and ground in a Willey mill, stored and analysed for various cations and anions. Standard methods were followed for all the sample analysis as per the standard methods.

The physico-chemical characteristics of the wastewater, soil, plant and organic amendments samples were analysed as per the standard methods prescribed by APHA (1998).

\section{Experimental details}

The field experiment was conducted at EMPEE breweries, Kanjikode, Palakkad by adopting randomized block design with three replications using brewery wastewater as an irrigation source. Under this experiment, wastewater is used at different dilutions to irrigate. Continuous application of wastewater was done with different dilutions.

A constructed mechanical device was used for the 50 per cent dilution. All the treatment combinations were randomly placed within each replication. The treatment details are described below.

\section{Treatment details (Table 1)}

$\mathrm{T}_{1}$ : Control

$\mathrm{T}_{2}$ : Irrigation with brewery wastewater +
Recommended Dose of NPK

$\mathrm{T}_{3}$ : Irrigation with brewery wastewater + Vermicompost + Recommended Dose of NPK

$\mathrm{T}_{4}$ : Irrigation with brewery wastewater + Brewery Sludge + Farm Yard Manure + Recommended Dose of NPK

$\mathrm{T}_{5}$ : Irrigation with mixture of brewery wastewater and water (1:1 ratio) + Recommended Dose of NPK

$\mathrm{T}_{6}$ : Irrigation with mixture of brewery wastewater and water (1:1 ratio) + Vermicompost + Recommended Dose of NPK

$\mathrm{T}_{7}$ : Irrigation with mixture of brewery wastewater and water (1:1 ratio) + Brewery Sludge + Farm Yard Manure + Recommended Dose of NPK

(Vermicompost at $3.5 \mathrm{t} \mathrm{ha}^{-1}$, Farm Yard Manure at $12.5 \mathrm{tha}^{-1}$ and Brewery Sludge at 2 $\mathrm{t} \mathrm{ha}^{-1}$ )

Organic materials used were vermicompost, farm yard manure and brewery industry sludge as per the recommendations.

\section{Results and Discussion}

\section{Characteristics of treated brewery wastewater}

The treated brewery wastewater collected from the United Breweries Ltd., Kanjikode, Palakkad, analyzed for important physical, chemical and biological properties and are presented in the Table 2. The brewery wastewater was colourless and odourless. The total dissolved solids content was $1320 \mathrm{mg} \mathrm{L}^{-}$ 1 , neutral in reaction (7.05) and the wastewater showed an electrical conductivity of $1.96 \mathrm{dS} \mathrm{m}^{-1}$. This is in line with the 
findings of Orhue et al., (2005). The brewery wastewater had dissolved oxygen content (DO) of $2.20 \mathrm{mg} \mathrm{L}^{-1}$, biochemical oxygen demand (BOD) of $32 \mathrm{mg} \mathrm{L}^{-1}$ and chemical oxygen demand of (COD) of $168 \mathrm{mg} \mathrm{L}^{-1}$. Among the nutrients, the nitrogen $(\mathrm{N})$ and potassium $(\mathrm{K})$ contents were higher, followed by phosphorus $(\mathrm{P})$. Being originated from the plant resources and fermentation process, the brewery wastewater contained considerable amount of plant nutrients. This is in accordance with Orhue et al., (2005) who reported that the brewery wastewater had a BOD of 1000 - $1500 \mathrm{mg} \mathrm{L}^{-1}$, suspended solids of $10-60 \mathrm{mg} \mathrm{L}^{-1}$, COD of $800-3000 \mathrm{mg} \mathrm{L}^{-1}$, plant nutrients of $\mathrm{N}$ and $\mathrm{P}$ of $30-100$ and 10 $30 \mathrm{mg} \mathrm{L}^{-1}$, respectively and Na content of 212 - $258 \mathrm{mg} \mathrm{L}^{-1}$. Among the cations, sodium (Na) was present in higher amount than $\mathrm{Ca}$ and $\mathrm{Mg}$. The sodium content of wastewater was $212 \mathrm{mg} \mathrm{L}^{-1}$ with a sodium adsorption ratio of 4.9. Among the micronutrients total iron was maximum $\left(25 \mathrm{mg} \mathrm{L}^{-1}\right)$, followed by total zinc $\left(20 \mathrm{mg} \mathrm{L}^{-1}\right)$, total copper $\left(3 \mathrm{mg} \mathrm{L}^{-1}\right)$ and manganese $\left(2 \mathrm{mg} \mathrm{L}^{-1}\right)$. The heavy metal and oil and grease contents were below detectable level. The microbial population of the brewery wastewater was $10 \times 10^{6} \mathrm{CFU}$ $\mathrm{ml}^{-1}$ for bacteria, $6 \times 10^{4} \mathrm{CFU} \mathrm{ml}{ }^{-1}$ for fungi and $3 \times 10^{2} \mathrm{CFU} \mathrm{ml}^{-1}$ for actinomycetes. The bioassay test indicating the survival rate of fish up to 94 per cent was recorded in brewery wastewater. The total coli forms count was nil.

\section{Initial characteristics of experimental field soil}

The soil collected from Kanjikode belongs to Palakkad plains Agro Climatic Zone with a soil type of red loam. The data on initial soil characteristics of the experimental site are presented in Table 3. The experimental soil was clay loam in texture. The soil was neutral (7.40) and non-saline (EC of $0.22 \mathrm{dS} \mathrm{m}^{-1}$ ). The organic carbon content was medium
(0.53 per cent). With regard to nutrient status, the soil was low in $\mathrm{N}\left(145 \mathrm{~kg} \mathrm{ha}^{-1}\right)$ and $\mathrm{P}$ $\left(15.8 \mathrm{~kg} \mathrm{ha}^{-1}\right)$ and medium in $\mathrm{K}\left(174 \mathrm{~kg} \mathrm{ha}^{-1}\right)$ levels. The exchangeable cationic concentrations of $\mathrm{Ca}, \mathrm{Mg}, \mathrm{Na}$ and $\mathrm{K}$ were $4.25,2.36,0.89$ and $0.21 \mathrm{cmol}\left(\mathrm{p}^{+}\right) \mathrm{kg}^{-1}$, respectively. The CEC of the soil was 8.19 cmol $\left(\mathrm{p}^{+}\right) \mathrm{kg}^{-1}$ with an ESP of 11.54. Based on the $\operatorname{ESP}(>15), \operatorname{EC~}\left(<4 \mathrm{dS} \mathrm{m}^{-1}\right)$ and $\mathrm{pH}(>$ $7.40)$, the soil falls under the classification of sodic soil. It had considerable population of microbes and appreciable level of enzyme activity. Considerable population of microorganisms (bacteria, fungi and actinomycetes) and enzyme (dehydrogenase, phosphatase and urease) activities were also assayed in the experimental field soil used for pot and field experiments.

\section{Characteristics of organic amendments used for field experiments}

The chemical constituents of various amendments used for field trials are given in Table 4. The $\mathrm{pH}$ of the organic amendments was neutral. Among the organic amendments, ETP sludge recorded an EC of $4.96 \mathrm{dS} \mathrm{m}^{-1}$, followed by vermicompost $\left(1.42 \mathrm{dS} \mathrm{m}^{-1}\right)$ and farm yard manure $\left(1.35 \mathrm{dS} \mathrm{m} \mathrm{m}^{-1}\right)$. The highest $\mathrm{N}$ and $\mathrm{P}$ contents were observed in vermicompost (1.68 per cent $\mathrm{N}$ and 1.42 per cent $\mathrm{P})$, followed by farm yard manure $(0.96$ per cent $\mathrm{N}$ and 0.80 per cent $\mathrm{P}$ ). The vermicompost also registered the highest $\mathrm{K}$ content of 1.16 per cent followed by ETP sludge (1.12 per cent) and farm yard manure ( 0.90 per cent). Higher organic carbon content was noticed in farm yard manure (24.20 per cent) followed by vermicompost (22.46 per cent) and ETP sludge (2.08 per cent). The C: $\mathrm{N}$ ratio of organic amendments ranged from 25.21:1 to $6.18: 1$. The amendments also had considerable amount of micronutrients and the brewery sludge recorded the maximum compared to other amendments. The amendments also contained considerable 
amount of micronutrients. This was in line with the findings of Kanagachandran and Jayaratne (2006); he reported that dry brewery sludge had appreciable quantities of nutrients like N (4.5\%), P (3.3\%), K (0.2\%), $\mathrm{Mn}\left(46 \mathrm{mg} \mathrm{kg}^{-1}\right), \mathrm{Zn}\left(75 \mathrm{mg} \mathrm{kg}^{-1}\right)$ and $\mathrm{Cu}(42$ $\left.\mathrm{mg} \mathrm{kg}^{-1}\right)$.

\section{Growth attributes of sesame under brewery wastewater irrigation}

The effect of amendments under brewery wastewater irrigation on growth of sesame was measured in terms of plant height and number of primary branches. The data of 90 days after sowing (DAS) showed that the brewery wastewater irrigation and the application of different levels of amendments markedly improved the growth of sesame (Table 4). In the cropping period, the plant height varied from 81.22 to $115.14 \mathrm{~cm}$ at 90 DAS. The number of primary branches ranged from 5 to 7 at 90 DAS. This effect was more pronounced at later stage of plant growth. While plants were shorter in soil with no amendments $\left(\mathrm{T}_{1}\right)$ of $81.22 \mathrm{~cm}$, taller on soil that received irrigation with brewery wastewater + vermicompost + RD of NPK $\left(T_{3}\right)$ of $115.14 \mathrm{~cm}$. Application of irrigation with brewery wastewater + vermicompost + $\mathrm{RD}$ of NPK $\left(\mathrm{T}_{3}\right)$ resulted the tallest plants. The number of primary branches was more in the treatment which received irrigation with mixture of brewery wastewater and water (1:1 ratio) + RD of NPK $\left(T_{5}\right)$ of 7 . The rest of the treatments produced average primary number of branches of 6 . Among the amendments, application of vermicompost at $3.5 \mathrm{t} \mathrm{ha}^{-1}+$ irrigation with brewery wastewater along with RD of NPK, followed by farm yard manure at $12.5 \mathrm{t} \mathrm{ha}^{-1}+$ brewery sludge $2 \mathrm{t} \mathrm{ha}^{-1}$ along with RD of NPK favoured plant growth parameters. These amendments supply higher quantity of nutrients, organic matter to the soil and increased the uptake of nutrients by plants because of increased availability of major and micronutrients added through brewery sludge and organic manures apart from inorganic fertilizers. Sivasamy (2004) also stated that the number of tillers and number of leaves in cumbu napier hybrid were more in pressmud + algae +50 per cent GR applied soil under paper mill effluent irrigation. Similar observations were also reported by Parameswari (2009) in garden land crops viz., maize, sunflower and napier grass under saline drainage water irrigation. Crop growth of sunflower increased with increase in dosage of $\mathrm{N}$ (Vijaya Kumar et al., 2003).

The poor performance occurred in plots that received irrigation with brewery wastewater along with RD of NPK $\left(\mathrm{T}_{2}\right)$, which might be due to poor soil organic matter and more of salinity stress due to continuous brewery wastewater irrigation. Similar results were also reported and the possible explanations for the cause of these effects are, (i) Salinity reduced the carbon translocation from the shoot (ii) It decreased the $\mathrm{N}$ uptake (Hawkins and Lewis, 1993) (iii) A higher proportion of the limited supply of root carbohydrates has to be used to generate ATP for osmoregulation and becomes unavailable for nitrate reduction (iv) Salinity inhibits the transport of nitrate from the root to the shoot (Cramer et al., 1995), which is replaced by the transport of amides but at a much lower level, a situation that decreases the amount of organic $\mathrm{N}$ available in the shoot for growth. Sumer et al., (2004) found that the reduction of maize growth under saline conditions involves both osmotic and ion effects.

\section{Yield attributes of crops}

The yield attributes of sesame (number of capsules per plant, number of seeds per capsule, number of seeds per capsule and test weight) were significantly improved with the addition of amendments in combination with 
brewery wastewater irrigation. The yield attributes viz., number of capsules per plant, capsule length, number of seeds per capsule, test weight and seed yield per plant in sesame were significantly influenced by the brewery wastewater irrigation and addition of different amendments (Table 5). The number of capsules ranged between 124 and 186. The numbers of seed capsule were increased in treatments of $T_{2}, T_{3}, T_{4}$ and $T_{5}$ over control. The seed capsule length was increased in all the treatments over control. The minimum number of capsules was noticed in $T_{5}$ and $T_{7}$ of 124 and was on par.

The higher yield attributes were observed under the treatments that received vermicompost than the other organic amendments. Plant biometrics directly correlated to the yield attributes. Addition of farm yard manure at $12.5 \mathrm{t} \mathrm{ha}^{-1}$ and brewery sludge at $2 \mathrm{t} \mathrm{ha}^{-1}$ might have supplied good amount of organic matter and NPK. The positive impact on the availability of individual plant nutrients, humic substances from organic manures and balanced supplement of nutrients through inorganic fertilizer might have induced the cell division, expansion of cell wall, meristematic activity, photosynthetic efficiency and regulation of water intake into the cells thus resulting in the better yield attributes of crops. These findings are in conformity with the results of Sharma et al., (2002) and Shankaraiah and Kalyanamurthy (2005).

Application of brewery wastewater and amendments had significant effect on number of seeds per capsule. The maximum number of seeds of 55.20 was observed in the treatment that received irrigation with brewery wastewater + vermicompost $+\mathrm{RD}$ of NPK $\left(T_{3}\right)$ followed by $T_{4}$ (irrigation with brewery wastewater + brewery sludge + farm yard manure + RD of NPK) of 53.28, which was on par with each other and the minimum number was noticed in $\mathrm{T}_{6}$ (irrigation with mixture of brewery wastewater and water (1:1 ratio) + vermicompost + RD of NPK) of 48.14. All the other treatments were on par with each other. The test weight of the sesame varied from 0.31 to $0.33 \mathrm{~g}$. The data on test weight of sesame indicated that the different dilution of brewery wastewater and amendments were on par with each other. Unlike test weight, the seed yield per plant was increased due to the application of amendments and concentration of brewery wastewater. The seed yield per plant was relatively more $(30.8 \mathrm{~g})$ in the treatment which received irrigation with brewery wastewater + vermicompost + RD of NPK $\left(\mathrm{T}_{3}\right)$ and was on par with the treatment $\mathrm{T}_{4}$ (27.6 g).

The tested field crop sesame in the present investigation recorded lower yield attributes in brewery wastewater with RD of NPK. These effects might be due to the salinity through brewery wastewater irrigation which generally inhibited the growth, yield attributes and yield through reduced water absorption, reduced metabolic activities due to $\mathrm{Na}^{+}$and $\mathrm{Cl}^{-}$toxicity and nutrients deficiency caused by ionic interference. These results are in agreement with findings of Mohamedin et al., (2006) and Parameswari (2009).

\section{Yield of crops}

The effects of amendments under brewery wastewater irrigation on sesame yield are presented in Table 5. The treatments had significant impact on crop residue and seed yield. The crop residue yield ranged from 3250 to $5267 \mathrm{~kg} \mathrm{ha}^{-1}$. While control $\left(\mathrm{T}_{1}\right)$ recorded the lowest yield, irrigation with brewery wastewater + vermicompost $+\mathrm{RD}$ of NPK $\left(\mathrm{T}_{3}\right)$ resulted in the highest crop residue yield (5267 $\mathrm{kg} \mathrm{ha}^{-1}$ ), followed by irrigation with brewery wastewater + vermicompost + RD of NPK $\left(T_{2}\right)$ of $4389 \mathrm{~kg} \mathrm{ha}^{-1}$. Lower the 
growth and yield of barley was recorded by Punith Raj et al., (2017) in treatment receiving irrigation with beverage industry effluent + RDF without gypsum which may be attributed to accumulation of salts. Addition of amendments along with brewery wastewater irrigation significantly improved the stover yield.

Table.1 Details of field experiments

\begin{tabular}{cll}
\hline SI No. & Particulars & Crop III \\
\hline 1. & Soil type & Red loam \\
2. & Crop & Sesame \\
3. & Variety & TMV (Sv) 7 \\
4. & Duration & $85-90$ days \\
5. & Number of treatments & 7 \\
6. & Number of replications & 3 \\
7. & Design & RBD \\
8. & Plot size & $5 \times 4 \mathrm{~m}$ \\
9. & Spacing & $30 \times 30 \mathrm{~cm}$ \\
10. & $\mathrm{~N}: \mathrm{P}: \mathrm{K}\left(\mathrm{kg} \mathrm{ha}^{-1}\right)$ & $30: 15: 15$ \\
\hline
\end{tabular}

Table.2 Characterization of treated brewery industrial wastewater

\begin{tabular}{lll}
\hline Parameters & Unit & Values \\
\hline Physical properties & & \\
\hline Colour & $\mathrm{Pt.} \mathrm{Co}$ & Colourless \\
Turbitity & $\mathrm{NTU}$ & 2 \\
Total suspended solids & $\mathrm{mg} \mathrm{L}^{-1}$ & 1.20 \\
Total dissolved solids & $\mathrm{mg} \mathrm{L}^{-1}$ & 1320 \\
Total solids & $\mathrm{mg} \mathrm{L}^{-1}$ & 1321.20 \\
\hline Physico-chemical properties & - & \\
\hline pH & - & 7.05 \\
Electrical conductivity & $\mathrm{dS} \mathrm{m}^{-1}$ & 1.96 \\
Dissolved oxygen & $\mathrm{mg} \mathrm{L}^{-1}$ & 2.20 \\
Biochemical oxygen demand & $\mathrm{mg} \mathrm{L}^{-1}$ & 32 \\
Chemical oxygen demand & $\mathrm{mg} \mathrm{L}^{-1}$ & 168 \\
Organic carbon & $\mathrm{per} \mathrm{cent}_{\text {Ammonical nitrogen }}$ & $\mathrm{BDL}$ \\
Nitrate nitrogen & $\mathrm{mg} \mathrm{L}^{-1}$ & 4.1 \\
Total Nitrogen & $\mathrm{mg} \mathrm{L}^{-1}$ & 45 \\
Total Phosphorus & $\mathrm{mg} \mathrm{L}^{-1}$ & 52 \\
Phosphate & $\mathrm{mg} \mathrm{L}^{-1}$ & 4 \\
Carbonate & $\mathrm{mg} \mathrm{L}^{-1}$ & 5 \\
Bicarbonate & $\mathrm{mg} \mathrm{L}^{-1}$ & 45 \\
Total alkalinity & $\mathrm{mg} \mathrm{L}^{-1}$ & 68 \\
Calcium & $\mathrm{mg} \mathrm{L}^{-1}$ & 713 \\
Magnesium & $\mathrm{mg} \mathrm{L}^{-1}$ & 39 \\
Sodium & $\mathrm{mg} \mathrm{L}^{-1}$ & 212 \\
Total Potassium & $\mathrm{mg} \mathrm{L}^{-1}$ & 28 \\
Chloride & $\mathrm{mg} \mathrm{L}^{-1}$ & 335
\end{tabular}




\begin{tabular}{|c|c|c|}
\hline Parameters & Unit & Values \\
\hline Sulphate & $\mathrm{mg} \mathrm{L}^{-1}$ & 48 \\
\hline Boron & $\mathrm{mg} \mathrm{L}^{-1}$ & 2 \\
\hline Per cent sodium & - & 55 \\
\hline Potential salinity (PS) & meq $\mathrm{L}^{-1}$ & 9.93 \\
\hline Sodium Adsorption Ratio (SAR) & - & 4.9 \\
\hline Residual Sodium Carbonate (RSC) & meq $\mathrm{L}^{-1}$ & -1.30 \\
\hline Iron & $\mathrm{mg} \mathrm{L}^{-1}$ & 25 \\
\hline Zinc & $\mathrm{mg} \mathrm{L}^{-1}$ & 20 \\
\hline Copper & $\mathrm{mg} \mathrm{L}^{-1}$ & 3 \\
\hline Manganese & $\mathrm{mg} \mathrm{L}^{-1}$ & 2 \\
\hline Chromium (VI) & $\mathrm{mg} \mathrm{L}^{-1}$ & $\mathrm{BDL}$ \\
\hline Total chromium & $\mathrm{mg} \mathrm{L}^{-1}$ & $\mathrm{BDL}$ \\
\hline Cadmium & $\mathrm{mg} \mathrm{L}^{-1}$ & BDL \\
\hline Lead & $\mathrm{mg} \mathrm{L}^{-1}$ & $\mathrm{BDL}$ \\
\hline Nickel & $\mathrm{mg} \mathrm{L}^{-1}$ & $\mathrm{BDL}$ \\
\hline Mercury & $\mathrm{mg} \mathrm{L}^{-1}$ & BDL \\
\hline Oil and grease & $\mathrm{mg} \mathrm{L}^{-1}$ & $\mathrm{BDL}$ \\
\hline \multicolumn{3}{|l|}{ Biological properties } \\
\hline Bacteria $\left(\mathrm{CFU} \mathrm{mL}^{-1}\right)$ & $10^{6}$ & 10 \\
\hline Fungi (CFU mL $\left.\mathrm{m}^{-1}\right)$ & $10^{4}$ & 6 \\
\hline Actinomycetes $\left(\mathrm{CFU} \mathrm{mL} \mathrm{mL}^{-1}\right)$ & $10^{3}$ & 3 \\
\hline Total coli form count & MPN $100 \mathrm{~mL}^{-1}$ & $\mathrm{BDL}$ \\
\hline $\begin{array}{l}\text { Bio - assay test (survival of fish after } 96 \mathrm{~h} \text { in } \\
100 \text { per cent effluent) }\end{array}$ & per cent & 94 \\
\hline
\end{tabular}

Table.3 Initial characteristics of experimental soil

\begin{tabular}{|c|c|}
\hline Parameters & Values \\
\hline \multicolumn{2}{|l|}{ Physico-chemical properties } \\
\hline $\mathrm{pH}$ & 7.40 \\
\hline $\mathrm{EC}\left(\mathrm{dS} \mathrm{m} \mathrm{m}^{-1}\right)$ & 0.22 \\
\hline Organic carbon (per cent) & 0.53 \\
\hline Available $\mathrm{N}\left(\mathrm{kg} \mathrm{ha}^{-1}\right)$ & 145 \\
\hline Available $\mathrm{P}\left(\mathrm{kg} \mathrm{ha}^{-1}\right)$ & 15.8 \\
\hline Available $\mathrm{K}\left(\mathrm{kg} \mathrm{ha}^{-1}\right)$ & 174 \\
\hline Exchangeable $\mathrm{Ca}\left(\mathrm{cmol}\left(\mathrm{p}^{+}\right) \mathrm{kg}^{-1}\right)$ & 4.25 \\
\hline Exchangeable $\mathrm{Mg}\left(\mathrm{cmol}\left(\mathrm{p}^{+}\right) \mathrm{kg}^{-1}\right)$ & 2.36 \\
\hline Exchangeable $\mathrm{Na}\left(\mathrm{cmol}\left(\mathrm{p}^{+}\right) \mathrm{kg}^{-1}\right)$ & 0.89 \\
\hline Exchangeable $\mathrm{K}\left(\mathrm{cmol}\left(\mathrm{p}^{+}\right) \mathrm{kg}^{-1}\right)$ & 0.21 \\
\hline \multicolumn{2}{|l|}{ Biological properties } \\
\hline Bacteria (x $10^{6} \mathrm{CFU} \mathrm{g}{ }^{-1}$ of soil) & 16 \\
\hline Fungi (x $10^{4} \mathrm{CFU} \mathrm{g}{ }^{-1}$ of soil) & 6 \\
\hline Actinomycetes ( $\mathrm{x} 10^{3} \mathrm{CFU} \mathrm{g}^{-1}$ of soil) & 3 \\
\hline Dehydrogenase ( $\mu \mathrm{g}$ of TPF $\mathrm{g}^{-1}$ of soil) & 5.8 \\
\hline Phosphatase ( $\mu \mathrm{g}$ of PNPP $\mathrm{g}^{-1}$ of soil) & 11.2 \\
\hline Urease $\left(\mu \mathrm{g} \mathrm{NH} \mathrm{NH}_{4}-\mathrm{Ng}^{-1}\right.$ of soil $\left.\mathrm{h}^{-1}\right)$ & 8.8 \\
\hline
\end{tabular}


Table.4 Characteristics of organic amendments

\begin{tabular}{lcccc}
\hline \multicolumn{1}{c}{ Parameters } & Unit & $\begin{array}{c}\text { Farm Yard } \\
\text { Manure }\end{array}$ & Vermicompost & $\begin{array}{c}\text { Brewery } \\
\text { sludge }\end{array}$ \\
\hline $\mathrm{pH}$ & - & 7.35 & 7.68 & 7.60 \\
Electrical conductivity & $\mathrm{dS} \mathrm{m}^{-1}$ & 1.35 & 1.42 & 4.96 \\
Organic carbon & per cent & 24.20 & 22.46 & 2.08 \\
Total Nitrogen & per cent & 0.96 & 1.68 & 0.34 \\
Total Phosphorus & per cent & 0.80 & 1.42 & 0.65 \\
Total Potassium & per cent & 0.90 & 1.16 & 1.12 \\
Total Calcium & per cent & 1.06 & 0.68 & 0.54 \\
Total Magnesium & per cent & 0.42 & 1.42 & 0.28 \\
C : N ratio & - & 25.21 & 13.37 & 6.18 \\
Iron & $\mathrm{mg} \mathrm{kg}^{-1}$ & 21.4 & 12 & 26.2 \\
Zinc & $\mathrm{mg} \mathrm{kg}^{-1}$ & 10.8 & 10 & 19.6 \\
Copper & $\mathrm{mg} \mathrm{kg}^{-1}$ & 146 & 16 & 212 \\
Manganese & $\mathrm{mg} \mathrm{kg}^{-1}$ & 45 & 12 & 112 \\
Cadmium & $\mathrm{mg} \mathrm{kg}^{-1}$ & 2 & 1.2 & 18 \\
Lead & $\mathrm{mg} \mathrm{kg}^{-1}$ & 4.6 & 2.4 & 6.5 \\
Nickel & $\mathrm{mg} \mathrm{kg}^{-1}$ & 2.2 & 1.2 & 2.2 \\
Chromium & $\mathrm{mg} \mathrm{kg}^{-1}$ & 1.2 & 0.8 & 0.6 \\
\hline
\end{tabular}

Table.5 Effect of treated brewery wastewater on the sesame growth, yield and quality parameters

\begin{tabular}{|c|c|c|c|c|c|c|c|c|c|c|c|}
\hline \multirow[b]{2}{*}{ Treatments } & \multirow[b]{2}{*}{$\begin{array}{c}\text { Plant } \\
\text { height } \\
(\mathbf{c m})\end{array}$} & \multirow{2}{*}{$\begin{array}{c}\begin{array}{c}\text { Number } \\
\text { of } \\
\text { primary }\end{array} \\
\text { branches }\end{array}$} & \multirow{2}{*}{$\begin{array}{c}\text { Number } \\
\text { of } \\
\text { capsules }^{-1} \\
\text { plant }^{-1}\end{array}$} & \multirow[b]{2}{*}{$\begin{array}{c}\text { Capsule } \\
\text { length } \\
(\mathrm{cm})\end{array}$} & \multirow{2}{*}{$\begin{array}{c}\text { Number } \\
\text { of seeds } \\
\text { capsule }_{1}^{-}\end{array}$} & \multirow[b]{2}{*}{$\begin{array}{c}\text { Test } \\
\text { weight } \\
\text { (g) }\end{array}$} & \multirow{2}{*}{$\begin{array}{l}\text { Seed } \\
\text { yield } \\
\text { plant } \\
{ }_{1}(\mathrm{~g})\end{array}$} & \multicolumn{2}{|c|}{$\begin{array}{c}\text { Yield } \\
\text { parameters }\end{array}$} & \multicolumn{2}{|c|}{$\begin{array}{c}\text { Quality } \\
\text { parameters }\end{array}$} \\
\hline & & & & & & & & $\begin{array}{c}\text { Crop } \\
\text { residue } \\
(\underset{1}{\text { kg ha }})^{-}\end{array}$ & $\begin{array}{c}\text { Seed } \\
\text { yield } \\
(\mathbf{k g} \\
\left.\mathrm{ha}^{-1}\right)\end{array}$ & $\begin{array}{c}\text { Crude } \\
\text { protein } \\
\text { (per } \\
\text { cent) }\end{array}$ & $\begin{array}{c}\text { Oil } \\
\text { content } \\
\text { (per } \\
\text { cent) }\end{array}$ \\
\hline $\mathbf{T}_{1}$ & 1.22 & 6 & 166 & 2.22 & 48.20 & 0.3 & 21.2 & 3250 & 532 & 13.71 & 38.23 \\
\hline $\mathbf{T}_{2}$ & 106.1 & 6 & 181 & 2. & 50.1 & 0.3 & 25.2 & 4389 & 610 & 14.02 & 40.13 \\
\hline $\mathbf{T}_{3}$ & 115.14 & 6 & 186 & 2.47 & 55.20 & 0.33 & 30.8 & 5267 & 804 & 14.23 & 41.32 \\
\hline $\mathbf{T}_{4}$ & 097.10 & 6 & 175 & 2.32 & 53.28 & 0.32 & 27.6 & 4531 & 757 & 13.74 & 40.62 \\
\hline $\mathbf{T}_{5}$ & 102.11 & 7 & 124 & 2.32 & 50.18 & 0.32 & 21.2 & 3581 & 433 & 13.69 & 40.10 \\
\hline $\mathbf{T}_{6}$ & 098.13 & 5 & 130 & 2.30 & 48.14 & 0.33 & 24.2 & 4250 & 609 & 14.12 & 40.24 \\
\hline $\mathbf{T}_{7}$ & 108.14 & 5 & 124 & 2.28 & 49.18 & 0.31 & 21.8 & 3680 & 482 & 13.76 & 41.00 \\
\hline Mean & 101.14 & 6 & 155 & 2.32 & 50.61 & 0.32 & 24.57 & 4135 & 603 & 13.90 & 40.23 \\
\hline SEd & 2.28 & 0.13 & 3.40 & 0.05 & 1.12 & 0.007 & 0.56 & 97.28 & 14.4 & 0.31 & 0.90 \\
\hline CD (0.05) & 4.96 & 0.27 & 7.42 & 0.11 & 2.44 & 0.016 & 1.23 & 211.95 & 31.3 & NS & NS \\
\hline
\end{tabular}

Treatments: $\mathrm{T}_{1}$ - Control; $\mathrm{T}_{2}$ - Irrigation with brewery wastewater $+\mathrm{RD}$ of NPK; $\mathrm{T}_{3}$ - Irrigation with brewery wastewater + Vermicompost + Recommended Dose of NPK; $\mathrm{T}_{4}$ - Irrigation with brewery wastewater + Brewery Sludge + Farm Yard Manure + Recommended Dose of NPK; $\mathrm{T}_{5}-$ Irrigation with mixture of brewery wastewater and water (1:1 ratio) + Recommended Dose of NPK; $\mathrm{T}_{6}$ - irrigation with brewery wastewater + Vermicompost + Recommended Dose of NPK; $\mathrm{T}_{7}$ - Irrigation with mixture of brewery wastewater and water (1:1 ratio) + Brewery Sludge + Farm Yard Manure + Recommended Dose of NPK; 
Table.6 Effect of treated brewery wastewater on the uptake of ions and nutrients in sesame

\begin{tabular}{|c|c|c|c|c|c|c|c|c|c|c|c|}
\hline \multirow{2}{*}{ Treatments } & \multicolumn{4}{|c|}{$\begin{array}{c}\text { Cations } \\
\left(\mathbf{k g ~ h a}^{-1}\right)\end{array}$} & $\begin{array}{c}\text { Anions } \\
\left(\mathbf{k g ~ h a}^{-1}\right)\end{array}$ & \multicolumn{4}{c|}{$\begin{array}{c}\text { Micronutrients } \\
\left(\mathbf{g ~ h a}^{-1}\right)\end{array}$} & \multicolumn{2}{c|}{$\begin{array}{c}\text { Macronutrients } \\
\left(\mathbf{k g ~ h a}^{-1}\right)\end{array}$} \\
\cline { 2 - 12 } & $\mathbf{C a}$ & $\mathbf{M g}$ & $\mathbf{N a}$ & $\mathbf{K}$ & $\mathbf{C l}$ & $\mathbf{C u}$ & $\mathbf{Z n}$ & $\mathbf{F e}$ & $\mathbf{M n}$ & $\mathbf{N}$ & $\mathbf{P}$ \\
\hline $\mathbf{T}_{\mathbf{1}}$ & 18.71 & 10.14 & 10.56 & 9.13 & 08.76 & 81 & 256 & 410 & 540 & 162.3 & 21.6 \\
\hline $\mathbf{T}_{\mathbf{2}}$ & 21.62 & 14.32 & 16.24 & 17.22 & 10.82 & 87 & 279 & 532 & 549 & 174.6 & 21.7 \\
\hline $\mathbf{T}_{\mathbf{3}}$ & 25.73 & 16.91 & 19.49 & 24.92 & 14.61 & 88 & 301 & 528 & 536 & 179.7 & 22.4 \\
\hline $\mathbf{T}_{\mathbf{4}}$ & 28.98 & 20.64 & 23.23 & 28.19 & 15.93 & 92 & 312 & 567 & 564 & 187.6 & 23.0 \\
\hline $\mathbf{T}_{\mathbf{5}}$ & 20.43 & 12.31 & 17.63 & 18.27 & 11.36 & 82 & 307 & 498 & 539 & 179.2 & 20.8 \\
\hline $\mathbf{T}_{\mathbf{6}}$ & 23.24 & 19.42 & 20.12 & 19.67 & 13.41 & 80 & 324 & 512 & 543 & 186.4 & 21.9 \\
\hline $\mathbf{T}_{\mathbf{7}}$ & 24.92 & 19.56 & 22.41 & 22.86 & 14.89 & 86 & 318 & 522 & 540 & 186.3 & 22.0 \\
\hline Mean & $\mathbf{2 3 . 3 8}$ & $\mathbf{1 6 . 1 9}$ & $\mathbf{1 8 . 5 3}$ & $\mathbf{2 0 . 0 4}$ & $\mathbf{1 2 . 8 3}$ & $\mathbf{8 5}$ & $\mathbf{3 0 0}$ & $\mathbf{5 1 0}$ & $\mathbf{5 4 4}$ & $\mathbf{1 7 9 . 4}$ & $\mathbf{2 1 . 9}$ \\
\hline SEd & $\mathbf{0 . 5 4}$ & $\mathbf{0 . 4 1}$ & $\mathbf{0 . 4 6}$ & $\mathbf{0 . 5 0}$ & $\mathbf{0 . 3 1}$ & $\mathbf{1 . 8 7}$ & $\mathbf{7 . 0 0}$ & $\mathbf{1 1 . 6 3}$ & $\mathbf{1 2 . 2 3}$ & $\mathbf{4 . 1 1}$ & $\mathbf{0 . 4 9}$ \\
CD $(\mathbf{0 . 0 5})$ & $\mathbf{1 . 1 8}$ & $\mathbf{0 . 9 1}$ & $\mathbf{1 . 0 0}$ & $\mathbf{1 . 0 9}$ & $\mathbf{0 . 6 7}$ & $\mathbf{4 . 0 8}$ & $\mathbf{1 5 . 2 4}$ & $\mathbf{2 5 . 3 5}$ & $\mathbf{N S}$ & $\mathbf{8 . 9 5}$ & $\mathbf{1 . 0 7}$ \\
\end{tabular}

Treatments: $\mathrm{T}_{1}-$ Control; $\mathrm{T}_{2}$ - Irrigation with brewery wastewater $+\mathrm{RD}$ of NPK; $\mathrm{T}_{3}-$ Irrigation with brewery wastewater + Vermicompost + Recommended Dose of NPK; $\mathrm{T}_{4}$ - Irrigation with brewery wastewater + Brewery Sludge + Farm Yard Manure + Recommended Dose of NPK; $\mathrm{T}_{5}{ }^{-}$ Irrigation with mixture of brewery wastewater and water (1:1 ratio) + Recommended Dose of NPK; $T_{6}$ - irrigation with brewery wastewater + Vermicompost + Recommended Dose of NPK; $\mathrm{T}_{7}$ Irrigation with mixture of brewery wastewater and water (1:1 ratio) + Brewery Sludge + Farm Yard Manure + Recommended Dose of NPK;

The seed yield varied from 433 to $804 \mathrm{~kg} \mathrm{ha}^{-1}$. Similar to crop residue yield, the different levels of amendments application had significant effect on seed yield. The seed yield recorded the highest $\left(804 \mathrm{~kg} \mathrm{ha}^{-1}\right)$ in the treatment $\mathrm{T}_{3}$ (irrigation with brewery wastewater + vermicompost + RD of NPK) followed by $\mathrm{T}_{4}$ (irrigation with brewery wastewater + farm yard manure + brewery sludge + RD of NPK) of $757 \mathrm{~kg} \mathrm{ha}^{-1}$, while the $\mathrm{T}_{5}$ recorded the lowest yield $\left(433 \mathrm{~kg} \mathrm{ha}^{-1}\right)$ which received irrigation with mixture of brewery wastewater and water $(1: 1$ ratio $)+$ RD of NPK.

The yield parameters are the indicators of crop yield. In general, application of amendment significantly increased seed and stalk yield of sesame. This might be due to the favourable effect of organic manures, which enhanced the fertility status of soil and improved the soil physical environment that might have promoted better germination, root proliferation, nutrient and water uptake by the crops (Hati et al., 2007). These results are in conformity with the findings of Pandey (2006).

The seed yield of sesame was higher in the treatment that received vermicompost $3.5 \mathrm{tha}$ $1+$ RD of NPK along with irrigation with brewery wastewater. The increase in yield of sesame was 50 per cent over control. Due to the overall significant improvement in yield attributes, crop yield was high in vermicompost followed by farm yard manure and brewery sludge in both the crops. This might be due to slow release of available nutrients throughout the crop growth period and also saline tolerant capacity of the tested crops. The increased yield could be attributed to the presence of essential nutrients in manures and leaching of soluble salts in root zone. Besides the primary nutrients, vermicompost, farm yard manure and brewery sludge also contained secondary nutrients like $\mathrm{Ca}, \mathrm{Mg}, \mathrm{S}$, trace elements which favored the removal of $\mathrm{Na}$ in soil, reduced the ESP and increased the crop growth and yield. 
Malarvizhi and Rajamannar (2001) and Parameswari (2009) also reported similar results on maize and sunflower crop.

\section{Quality parameters}

The crude protein and oil content of sesame were improved significantly due to brewery wastewater irrigation and the addition of amendments (Table 5). Among the different organic amendments, the irrigation with brewery wastewater + vermicompost $+\mathrm{RD}$ of NPK $\left(T_{3}\right)$, recorded the highest crude protein of 14.23 per cent and oil content of 41.32 per cent. The lowest crude protein of 13.71 per cent and oil content of 38.23 per cent was observed in control $\left(\mathrm{T}_{1}\right)$ followed by $\mathrm{T}_{2}$ (Irrigation with brewery wastewater $+\mathrm{RD}$ of NPK). The results showed non significance among the various treatments. The addition of amendments substantially increased the quality parameters of crops viz., crude protein and oil content of sesame. Similar to yield, amendment application increased the quality parameters significantly.

Among the different amendments, application of vermicompost at $3.5 \mathrm{t} \mathrm{ha}^{-1}$ and farm yard manure@12.5 t ha ${ }^{-1}+$ brewery sludge@2 t $\mathrm{ha}^{-1}$ along with brewery wastewater irrigation recorded higher quality parameters in sesame. Addition of amendments along with brewery wastewater irrigation might have provided enough nutrients with better physical and microbial environment, thus improving the soil fertility, which ultimately enhanced crop growth and yield and resulted in improved quality parameters.

This is in agreement with the observations of Parameswari (2009), who reported that the maize, sunflower and cumbu napier grass in drainage water irrigated soil receiving NPK with pressmud or FYM or gypsum as amendment recorded higher values of $\mathrm{N}, \mathrm{K}$, crude protein and amino acid content.

\section{Ions uptake}

Addition of brewery wastewater and amendments significantly increased the uptake of cations and anions (Table 6). The uptake of cations varied from 18.71 to 28.98 , 10.14 to $20.64,10.56$ to $23.23,9.13$ to 28.19 $\mathrm{kg} \mathrm{ha}^{-1}$ of $\mathrm{Ca}, \mathrm{Mg}, \mathrm{Na}$ and $\mathrm{K}$, respectively, whereas the anion $\mathrm{Cl}$ ranged from 8.76 to $15.93 \mathrm{~kg} \mathrm{ha}{ }^{-1}$. The maximum uptake of cations and anions were noticed in the treatment $T_{4}$ followed by $T_{3}$ and was on par and the minimum uptake was observed in control $\left(\mathrm{T}_{1}\right)$.

Application of Irrigation with brewery wastewater + brewery sludge + farm yard manure $+\mathrm{RD}$ of $\mathrm{NPK}\left(\mathrm{T}_{4}\right)$ registered the highest $\mathrm{N}$ uptake $\left(187.6 \mathrm{~kg} \mathrm{ha}^{-1}\right)$ compared to $\mathrm{T}_{1}$ $\left(162.3 \mathrm{~kg} \mathrm{ha}^{-1}\right)$. The result indicated that the brewery wastewater and amendments application significantly increases the plant nitrogen uptake. The $\mathrm{P}$ uptake by sesame crop ranged between 20.8 and $23.0 \mathrm{~kg} \mathrm{ha}^{-1}$. The $\mathrm{P}$ uptake by sesame crop was higher in $T_{4}$ (irrigation with brewery wastewater + brewery sludge + farm yard manure + RD of NPK) of $23.0 \mathrm{~kg} \mathrm{ha}^{-1}$ followed by $\mathrm{T}_{3}\left(22.4 \mathrm{~kg} \mathrm{ha}^{-1}\right)$ and the lowest being registered in $\mathrm{T}_{5}$ (irrigation with mixture of brewery wastewater and water (1:1 ratio) + RD of NPK) of $20.8 \mathrm{~kg} \mathrm{ha}^{-1}$.

The $\mathrm{Zn}$ uptake by sesame crop varied between 256 and $324 \mathrm{~g} \mathrm{ha}^{-1}$ (Table 6). The treatment $\mathrm{T}_{6}$ registered the highest value of $324 \mathrm{~g} \mathrm{ha}^{-1}$ followed by $\mathrm{T}_{7}$ (irrigation with mixture of brewery wastewater and water $(1: 1$ ratio) + farm yard manure + brewery sludge $+\mathrm{RD}$ of NPK) of $318 \mathrm{~g} \mathrm{ha}^{-1}$ and the lowest being recorded in $\mathrm{T}_{1}$ (control) of $256 \mathrm{~g} \mathrm{ha}^{-1}$. The $\mathrm{Cu}$, $\mathrm{Fe}$ and $\mathrm{Mn}$ uptake by sesame crop ranged from 81 to 92,410 to 567 and 536 to $564 \mathrm{~g}$ $\mathrm{ha}^{-1}$, respectively. The treatment $\mathrm{T}_{4}$ (irrigation with brewery wastewater + brewery sludge + farm yard manure + RD of NPK) recorded the highest value $\left(92,567\right.$ and $564 \mathrm{~g} \mathrm{ha}^{-1}$ 
respectively). Among the method of application of brewery wastewater and amendments, there was no marked difference in the micronutrients uptake by sesame crop. Significant improvement was observed in the cations $(\mathrm{Ca}$, $\mathrm{Mg}, \mathrm{Na}$ and $\mathrm{K}$ ) and anions $(\mathrm{Cl})$ uptake by the sesame crop in amendments applied plots. Such improvements were possibly due to the enhanced biomass of the crop thereby increased the uptake of cations and anions. The minimum uptake of cations and anions were observed in control.

The ion uptake was maximum in the treatment that received farm yard manure @ 12. $5 \mathrm{t} \mathrm{ha}^{-1}+$ brewery sludge @ $2 \mathrm{t} \mathrm{ha}^{-1}$ with brewery wastewater. The brewery wastewater and amendments treated plots received carbon sources and other nutrients that promoted greater microbial and enzyme activities in soil which in turn facilitated higher rate of mineralization leading to addition of nutrients to soil. The amendment application, because of its organic matter content, might have improved the soil physical conditions, favouring better root and shoot growth and nutrients uptake. In the present study, both the crops exhibited maximum uptake of cations than anions. The results on cations and anions uptake by crops are in agreement with the findings of De Lacerda et al., (2003). It was reported that $\mathrm{Na}^{+}$uptake increased and $\mathrm{K}^{+}$ uptake decreased in plants and high levels of $\mathrm{Na}^{+}$inhibited the $\mathrm{K}^{+}$concentration in sunflower plants and as a result it caused an increase in the $\mathrm{Na}^{+} / \mathrm{K}^{+}$ratio.

Based on the above results from field trials, it could be concluded that, the sesame crop performed well under brewery wastewater irrigation along with different amendments. The continuous reuse of brewery wastewater might lead to a salinity buildup, as well as contribute to the deterioration of soil quality. But in Palakkad region due to the even distribution of rain with high intensity, one season of crop might be under rainfed condition which might dilute the pollutants and be utilized during the next cropping season. This problem could be effectively managed by the use of soil amendments (farm yard manure at $12.5 \mathrm{t} \mathrm{ha}^{-1}$ and vermicompost along with 100 per cent brewery wastewater and NPK).

\section{Acknowledgement}

I am extremely thankful to the funding agency United Breweries Ltd (UBL)., Kanjikode, Palakkad, Kerala and its staff members for their support in successful completion of field experiments at EMMPEE Brewery premises, Kanjikode, Palakkad. I express my sincere gratitude to Tamil Nadu Agricultural University, Coimbatore for all the facility.

\section{References}

APHA. 1980. Standard methods for the examination of water and wastewater, $16^{\text {th }}$ edition. American Public Health Association, Washington DC. pp.81-96.

APHA. 1998. Standard methods for the examination of water and wastewater, $20^{\text {th }}$ edition, American Public Health Association, Washington D.C.

Cramer, M.D., A. Schierholt, Y.Z. Wang and S.H. Lips. 1995. The influence of salinity on the utilization of root anaplerotic carbon and nitrogen metabolism in tomato seedlings. $J$. Exp. Bot., 46: 1569-1577.

Genner, C. 1988. Treatment and disposal of brewery effluents. Brewers Guardian. October. 25-27.

Hati, K.M., A.K. Biswas, K.K. Bandyopadhyay and A.K. Misra. 2007. Soil properties and crop yields on a vertisol in India with application of distillery effluent. Soil Tillage Res., 92: 60-68.

Hawkins, H.J and O.A.M. Lewis. 1993. Combination effect of $\mathrm{NaCl}$ salinity, nitrogen form and calcium concentration on the growth, ionic content and gaseous exchange properties of Triticum aestivum. 
New Phytol., 124: 161-170.

Ishiwaki, N., H. Murayama, H. Awayama, O. Kanauvhi and T. Sato. 2000. Development of high value uses of spent grain by fractionation technology. MBAA Technic., (37): 261-265.

Kanagachandran, K and R. Jayaratne. 2006. Utilization potential of brewery wastewater sludge as an organic fertilizer. J. Inst. Brew., 112(2): 92-96.

Malarvizhi, P and A. Rajamannar. 2001. Efficient utilization of sewage water for improving the forage yield and quality of bajra and napier hybrid grass. Madras Agric. J., 88: 477-482.

Manjunatha, B.N., S. Bhaskar and Shivaramu, H.S. 2017. Maize Response, Changes in Soil Available Nutrients and Microbial Population as Influenced by Brewery Wastewater Irrigation. Int. J. Curr. Microbiol.App. Sci. 6(4): 2712-2720.

Mohamedin, A.A.M., A.A. Abd El-Kader and N.M. Badran. 2006. Response of sunflower (Helianthus annuus L.) to plants salt stress under different water table depths. J. Appl. Sci. Res., 2(12): 1175-1184.

Orhue, E.R., A.U. Osaigbovo, O. Osahon and E. Dennis. 2005. Growth of Maize ( Zea mays L.) and changes in some chemical properties of an ultisol amended with brewery effluent. Afri. J. Biotech., 4(9): 973-978.

Pandey, S. N., 2006, Effect of brewery effluent on seedlings of Cajanus cajan and Vigra mungo. J. Appl. Bio-sci., 32(1): 199-122.

Parameswari, E. 2009. Impact of agricultural drainage water on crops under sequential biological concentration system and use of nanoparticles for wastewater treatment.
Ph.D., thesis, Tamil Nadu Agricultural University, Coimbatore.

Punith Raj T.S., C.A. Srinivasamurthy, S. Bhaskar and Prabhudev Dhumgond and Prakash, S.S. 2017. Effect of Beverage Industry Effluent Irrigation on Growth and Yield of Barley. Int. J. Curr. Microbiol. App. Sci. 6(4): 2403-2413.

Qadir, M., T.M. Boers, S. Schubert, A. Ghafoor and G. Murtaza. 2003. Agricultural water management in water-starved countries: Challenges and opportunities. Agric. Water Manage., 62: 165-185.

Shankaraiah, C and K.N. Kalayanamurthy. 2005. Effect of enriched pressmud cake on growth, yield and quality of sugarcane. Sugar Technol., 7: 1-4.

Sharma, B.L., S. Singh, S. Sharma, Vedaprakash and R.R. Singh. 2002. Integrated response of pressmud cake and urea on sugarcane in calcareous soil. Co-operative Sugar, 33: 1001-1004.

Sivasamy, N. 2004. Phytoremediation potential of fodder crops in paper mill effluent polluted soil habitat. M.Sc., Thesis, Tamil Nadu Agricultural University, Coimbatore.

Sumer, A., C. Zorb, F. Yan and S. Schubert. 2004. Evidence of sodium toxicity for the vegetative growth of maize (Zea mays) during the first phase of salt stress. J. Appl. Bot., 78: 135-139.

Vijaya Kumar, M., P. Subbian, A.C. Lourduraj, R. Selvaraju and S. Ramesh. 2003. Effect of split application of nitrogen and interaction effect of nitrogen and plant population on growth and yield of sunflower (Helianthus annuus L.) A review. Agric. Rev., 24(4): 303-307.

\section{How to cite this article:}

Senthilraja, K. 2017. Effect of Brewery Effluent Irrigation and Sludge Application in Combination with Organic Amendments on Growth and Yield of Sesame (Sesamum indicum L.). Int.J.Curr.Microbiol.App.Sci. 6(12): 965-977. doi: https://doi.org/10.20546/ijcmas.2017.612.107 